\title{
MICRORADIOGRAPHIC AND MICROHARDNESS STUDIES OF DEVELOPING ENAMEL
}

\author{
JAMES K. AVERY \\ The University of Michigan School of Dentistry, Ann Arbor, Michigan, U.S.A.
}

\begin{abstract}
This study was undertaken on human and Rhesus monkey enamel using three methods of analysis to gain information concerning the pattern of enamel calcification: (1) microhardness pattern of enamel mineralization; (2) microradiography; and (3) plastic substitution studies. Halves of teeth were selected and tested on a Tukon Microhardness Tester with a Knoop Diamond Indentor. The other half of each tooth was further sectioned. Several sections from each tooth were ground to less than $150 \mu$ in thickness and microradiographs were taken; the remainder were used for the substitution studies. All organic tissue and water were removed from the sections and replaced with plastic. Decalcification of these sections revealed areas of low and high organic and water content. It was found that mineralization of the enamel matrix begins at the dentino-enamel junction and proceeds peripherally, thus following the incremental pattern of formation of the enamel matrix. Final calcification is completed after the matrix is completely deposited and follows this same pattern from the dentinoenamel junction peripherally. The enamel rod matrix becomes calcified before the interrod substance, the latter thus presenting pathways for diffusion of tissue fluid containing calcium and phosphate ions, during the mineralization process. The interrod substance is the first area of enamel to be altered in dental caries. Thus the steps in enamel destruction are in reverse order to those in enamel formation.
\end{abstract}

Zusammenfassung-Die Verkalkung des Zahnschmelzes von Rhesusaffen und Menschen wurde mit Hilfe von (1) Mikrohärteprüfungen, (2) Mikroradiographien und (3) Substitution des organischen Materials untersucht. Aus jedem Zahn wurde Material für alle drei Untersuchungsmethoden gewonnen.

Die Ergebnisse zeigen, dass die Verkalkung der Schmelzmatrix an der SchmelzDentin-Grenze beginnt und gegen die Peripherie fortschreitet, demnach also in der gleichen Reihenfolge wie die Bildung der Schmelzmatrix abläuft. Die endgültige Mineralisation findet erst nach vollständigem Abschluss der Matrixbildung statt und erfolgt ebenfalls zentrifugal mit Beginn an der Schmelz-Dentin-Grenze. Die Prismenmatrix wird vor der interprismatischen Substanz verkalkt, wobei die letztere während des ganzen Verkalkungsvorgangs die Diffusionsbahnen für die Calcium- und Phosphationen enthaltende Gewebsflüssigkeit darstellt. Umgekehrt wird die interprismatische Substanz bei einer kariösen Entkalkung zuerst verändert.

Résumé-L'auteur a étudié l'émail humain et celui de Macacus Rhesus à l'aide de microdéterminations de dureté (Tukon Microhardness Tester muni d'un Knoop Diamond Indentor), de microradiographies et d'études par substitution des minéraux par une matière plastique. Chaque dent étudiée a été sectionnée par moitié, une moitié servant aux mesures de dureté, l'autre étant débitée en coupes (polies à moins de 150 microns d'épaisseur) destinées soit à la microradiographie, soit à la déminéralisation (EDTA) et la déshydratation conduisant à la substitution plastique.

La déminéralisation révèle une distribution hétérogène des constituants immédiats de l'émail. La minéralisation de l'organe adamantin procède excentriquement à partir de la 
jonction dentine-émail. suivant étroitement la croissance de la matrice de l'émail. La minéralisation s'achève ainsi quand a pris fin la formation de la matrice. Au niveau des prismes, la formation matricielle se minéralise avant le matériel interprismatique, ce dernier laissant des voies de diffusion ouvertes aux ions minéraux apportés par les tissus.

Comme d'autre part la substance interprismatique serait la première altérée dans la lésion carieuse, on peut concevoir son mécanisme aggressif comme semblable-mais à rebours-à celui qui a assuré la minéralisation normale de l'émail.

\section{INTRODUCTION}

AN evaluation of the voluminous literature concerning enamel mineralization indicates that two general concepts of the process have been developed. The first of these concepts holds that the mineralization of enamel follows the pattern of formation of the enamel matrix; that is, from the dentino-enamel junction peripherally. ${ }^{(1-12)}$ The second concept postulates that enamel matrix formation and final mineralization are separate processes, the latter not beginning until after the former is complete. ${ }^{(13-22)}$ According to the second concept, mineralization of the enamel matrix begins at the tip of the cusp and proceeds cervically in a direction perpendicular to the increments of matrix deposition.

Recently the theory of mineralization from the dentino-enamel junction peripherally has been strengthened by convincing evidence revealed by fluorescence and polarizing microscopy, ${ }^{(1)}$ electron microscopy ${ }^{(23,24)}$ radioisotopes $^{(25,26)}$ and microradiography..$^{(2,8-12)}$ Furthermore, the microradiographic findings of a gradient of mineral concentration decreasing from the dentino-enamel junction peripherally have been confirmed by a recent study of the birefringence of enamel. ${ }^{(27)}$ However, it would be of interest to learn whether or not the total amount of pre-eruptive mineral content had been accounted for. Radioautographic and microradiographic techniques have shown the relative distribution of mineral but they have not given any quantitative assessment. Therefore, the latest investigations have not ruled out a secondary mineralization or maturation of enamel matrix as has been indicated by quantitative chemical analysis of developing enamel. ${ }^{(18)}$

In the present study an effort was made to determine the amount and distribution of mineral in all stages of enamel mineralization. Microradiography and microhardness testing were the techniques of choice. It was believed that correlation of the findings would give information on the process of enamel mineralization which would indicate whether or not there are two distinct stages in the calcification of enamel matrix.

\section{MATERIALS AND METHODS}

Twenty-two teeth were obtained at autopsy from humans aged two and one-half, three, four, and four and one-half years. Thirty-four developing teeth were taken from six Rhesus monkeys, one to three years of age. The teeth were grouped into developmental stages according to the extent of formation and calcification as indicated by conventional radiographs. The teeth then were dissected from the jaws, photographed (Fig. 1), dehydrated and embedded in quick-setting plastic (to prevent 
infiltration). They were bisected by means of a water-cooled cutting disk* and onehalf of each tooth then was serial sectioned at approximately 75 micra for microradiographic study. The proper time of radiographic exposure was determined for each section by measuring its thickness with a micrometer. The thin sections were stored in distilled water until ready for use, at which time they were dried and placed in direct contact with spectroscopic plates. $\dagger$ Microradiographs were taken at $10 \mathrm{kV}$. This voltage gives $\mathrm{X}$-rays of a wave length of approximately $2 \cdot 2 \AA$, the proper wave length for maximal absorption by calcium ions. The sections were exposed to $30 \mathrm{~mA}$ for 35 to $70 \mathrm{~min}$, depending upon the thickness of the section, The microradiographs then were developed in Kodak D-19 for five minutes at $68^{\circ} \mathrm{F}$. negatives of the plates prepared and enlarged prints made for study.

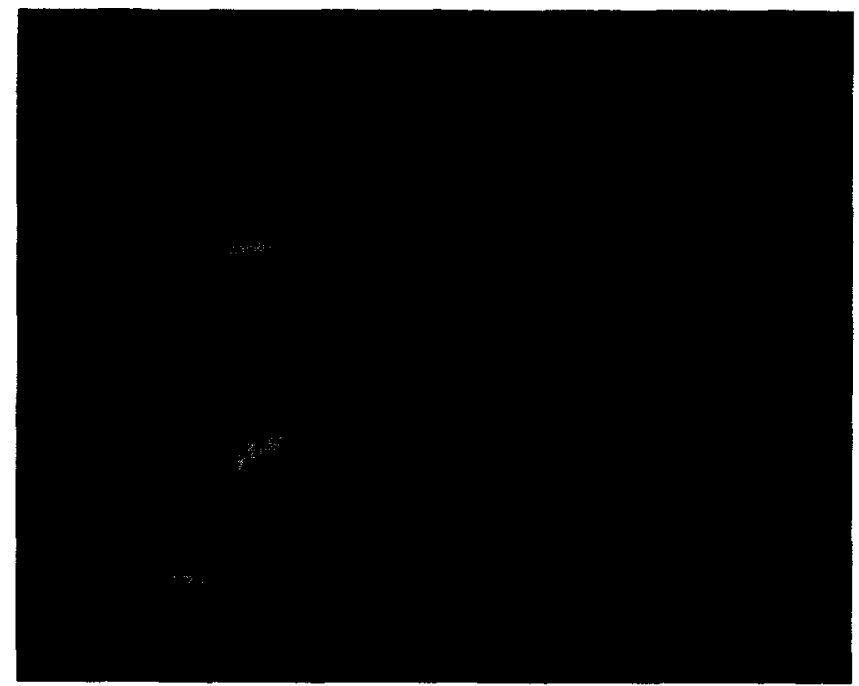

FIG. 1. Photograph of developing human crowns. Observe "formalin brown" in contrast to white, more highly calcified cusp tip. This effect is not observed in the interior of the enamel as noted in teeth on right.

Microhardness testing was done on the other halves of the plastic-embedded crowns. They were cut into section $\frac{1}{2} \mathrm{~mm}$ thick, affixed to plastic slides and polished. Using a $25 \mathrm{~g}$ weight, the enamel was tested for microhardness. + The only indentations recorded were uniform ones showing a diamond-shaped impression with a length seven times greater than the width. A sufficient number of hardness tests were made on each sample so that all areas of the enamel were evaluated. This amounted to as few as 35 measurements in young teeth with limited areas of sufficient hardness for testing, to as many as 100 to 125 measurements on more mature teeth. In

\footnotetext{
* Gillings-Hamco Thin Sectioning Machine, Hamco Machines, Inc., Rochester, N.Y.

$\dagger$ Kodak Type 649. 0 .

$\ddagger$ Tukon Microhardness Tester with a Knoop Diamond Indenter.
} 
order to facilitate interpretation of the hardness measurements, a magnified image of each crown was projected and traced. On these tracings zones exhibiting a range of 30 Knoop Hardness Numbers (KHN) were outlined.

\section{FINDINGS}

Microradiography-A narrow, radiopaque band measuring 35 to 50 micra in width and located at the dentino-enamel junction was the only microradiographic evidence of mineralization (Fig. 2.) This narrow band was the first such evidence of minerali-

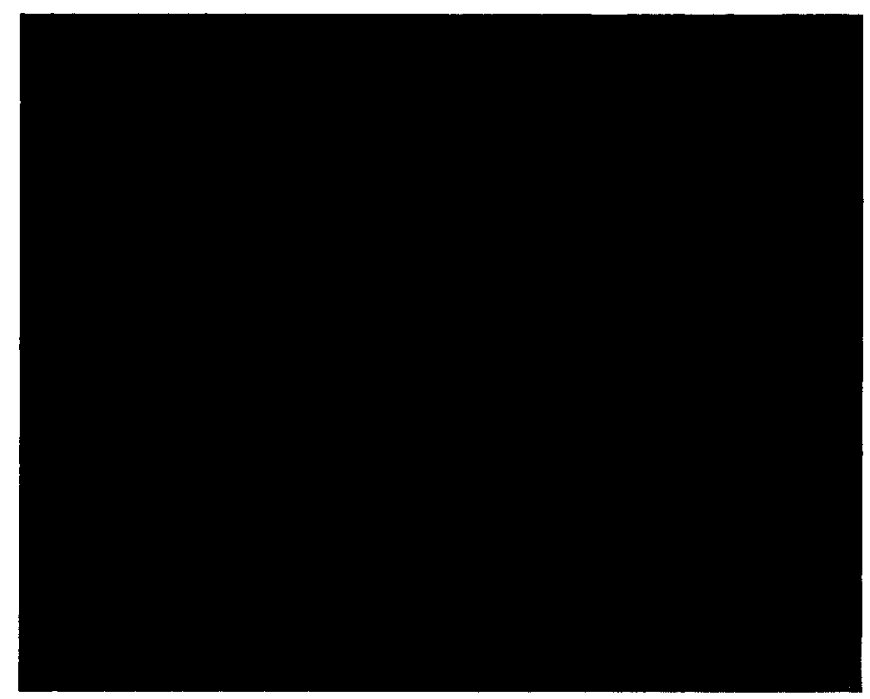

FrG. 2. Microradiograph of a mesiodistal section of a young monkey tooth illustrating radiodense line along the dentino-enamel junction.

zation and was seen even in the most cervical areas of the crown. At this location the width of enamel matrix and the length of time that it has been deposited are much less than at the cusp tip. At a later stage of development the incremental lines (lines of Retzius) appeared to be more highly mineralized than the adjacent intervening matrix (Fig. 3). As mineralization progresses peripherally from the dentino-enamel junction, the incremental lines at the cusp tips become masked. At later stages the same masking was seen in more cervical areas of the developing crowns. During these early stages of calcification radiodense enamel rods and radiolucent interrod* substance were revealed in high-magnification microradiographs. The uncalcified area between the rods was found to be wider in young, calcifying enamel than in more completely calcified enamel (Fig. 4). Thus it appears that, just as in matrix deposition, the mineralization of young enamel follows an incremental or nearly

* The term "interrod" is preferred to "interprismatic" because the prismatic (eight-sided) shape of enamel rods has been disproved (see ref. 23). 


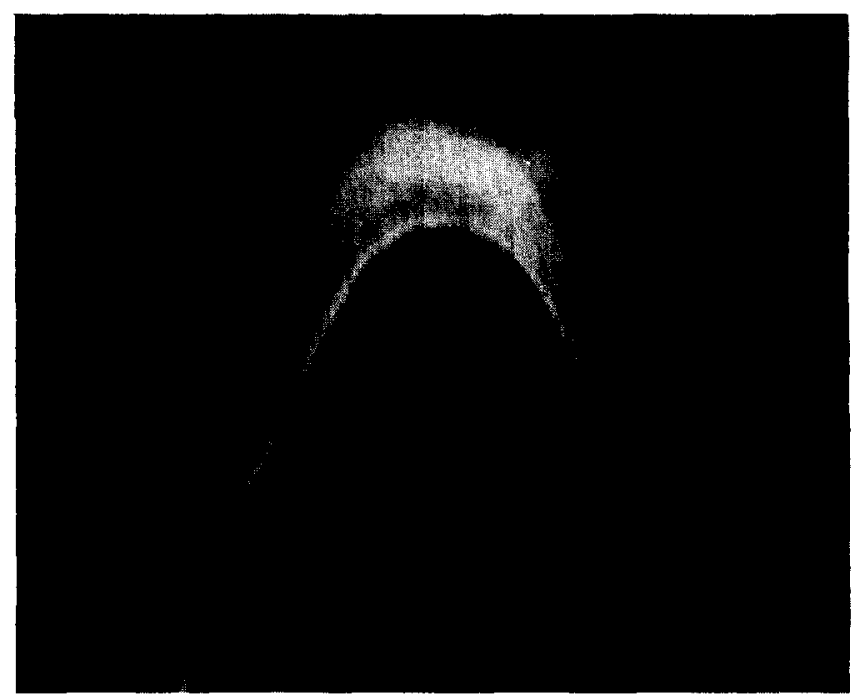

Fig. 3. Microradiograph of a human molar illustrating an area of increased mineral density spreading from the dentino-enamel junction and obscuring the incremental lines.

FIG. 4. A high magnification microradiograph of enamel illustrating contrast between calcifying enamel rods and radiolucent interrod substance.

incremental pattern peripherally from the dentino-enamel junction. The mineral appeared to diffuse from the oldest matrix into the younger matrix rather than being limited to a certain number of increments behind matrix formation.

Young, calcifying enamel matrix presented varied characteristics in the micro- 
radiographs. For example, in some specimens alternate Schreger bands exhibited different degrees of radiodensity. In other specimens were areas of unexplained opacity or lucidity, due, perhaps, to pathology of the enamel. One factor which could account for most of the variations from the general pattern is that the sections were not ground exactly plano-parallel. To do this, however, would be most difficult, if not impossible.

Eventually the enamel appeared uniformly radiopaque and no further information on mineral content could be obtained by microradiography. At this stage it was necessary to continue by microhardness testing.

Microhardness-Only the oldest, most uniformly radiopaque teeth were sufficiently hard to obtain accurate indentations with the Tukon Microhardness Tester. At the stage of mineralization when the enamel first shows a uniform radiopacity, the Knoop Hardness Number (KHN) was 100 or higher and apparently represents only a small amount of the final mineral content since the KHN of adult human enamel is $343 \pm 23 .^{(28)}$ This finding is illustrated in Fig. 5, a microradiograph, and in Fig. 7 which shows the hardness pattern of the same tooth.

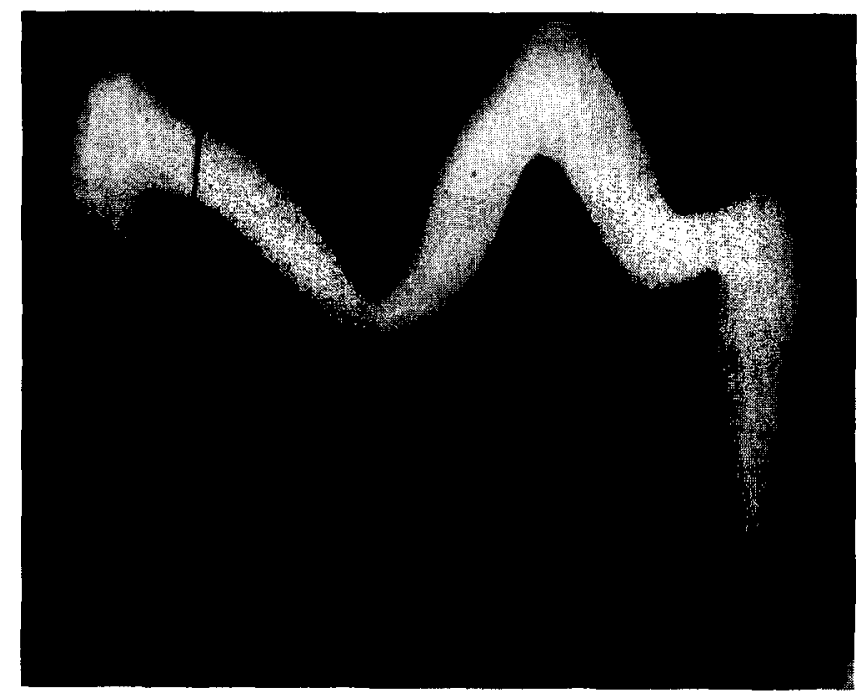

FIG. 5. Microradiograph of enamel of molar showing uniform density throughout.

In both human and monkey enamel the first areas of measurable hardness were along the dentino-enamel junction and in a narrow, adjacent zone at the cusp tips. This 35- to 50-micra band had hardness values ranging from 150 to $380 \mathrm{KHN}$ and was found to be consistently harder in the cusp than in the more cervical areas of the crown. Except in the region of the cusp tip, the enamel more than 50 micra from the dentino-enamel junction was too soft to be measured. In these teeth no pattern of relative hardness could be obtained. In a slightly more calcified tooth 
hardness values decreased from 280 to $30 \mathrm{KHN}$ as the indenter moved from the band along the dentino-enamel junction to the periphery of the cusp.

At a later stage in development a wider range of hardness values was apparent. At the dentino-enamel junction the hardness was similar to that in the previous tooth but a greater mineral content was evident peripherally. The hardness values in this specimen ranged from $270 \mathrm{KHN}$ to 30 to $0 \mathrm{KHN}$ in the very soft areas at the cervical portion of the crown (Fig. 6). The nine zones of hardness values in the enamel present an incremental pattern very similar to that of matrix deposition. However, these zones pertain only to the $30 \mathrm{KHN}$ ranges of microhardness values and are not to be attributed to any morphologic appearance of enamel matrix such as is indicated by the lines of Retzius.

In other crowns studied the microhardness values ranged from 0 to $400 \mathrm{KHN}$. Zone 1 represents enamel which is as hard as that found in adult enamel. In succeeding zones the hardness values decreased peripherally from the dentino-enamel junction in an incremental pattern following the chronology of matrix deposition. The widest range of hardness values was found in the enamel of these teeth and therefore the greatest number (10) of zones of hardness.

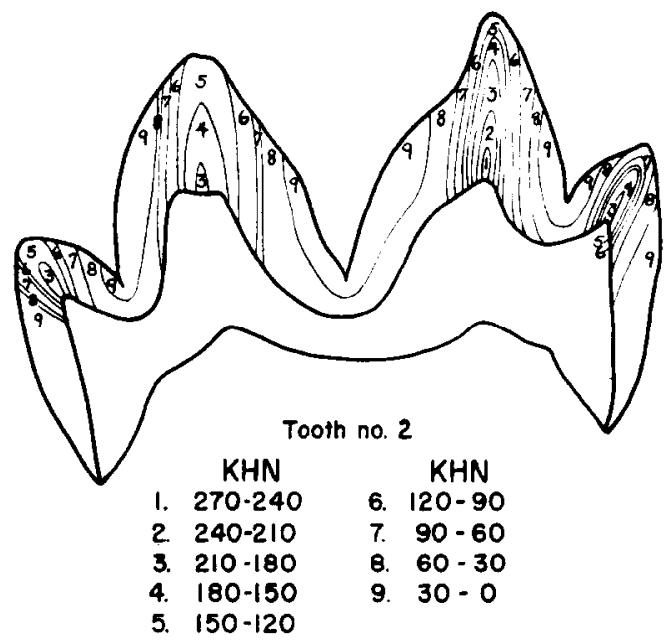

$25 \mathrm{gm}$. weight

FIG. 6. Projection diagram of a mesiodistal section of a monkey molar. The hardness values grouped in increments of $30 \mathrm{KHN}$ indicate the pattern of enamel hardness.

In the next older specimen increased mineralization eliminated the three zones of lowest microhardness values, and the areas of maximum hardness increased in size (Fig. 7). The latter areas were located at the cusp tips and were uniformly mineralized. The less hard areas still exhibited an incremental pattern and were found in grooves between the cusps and at the cervical region of the crown. No areas of less than $90 \mathrm{KHN}$ were found. 
The oldest tooth studied was in the process of eruption but had not yet emerged into the oral cavity. All areas of the enamel were within the range of adult hardness and no incremental pattern of mineral density was indicated by the measurements (Fig. 8).

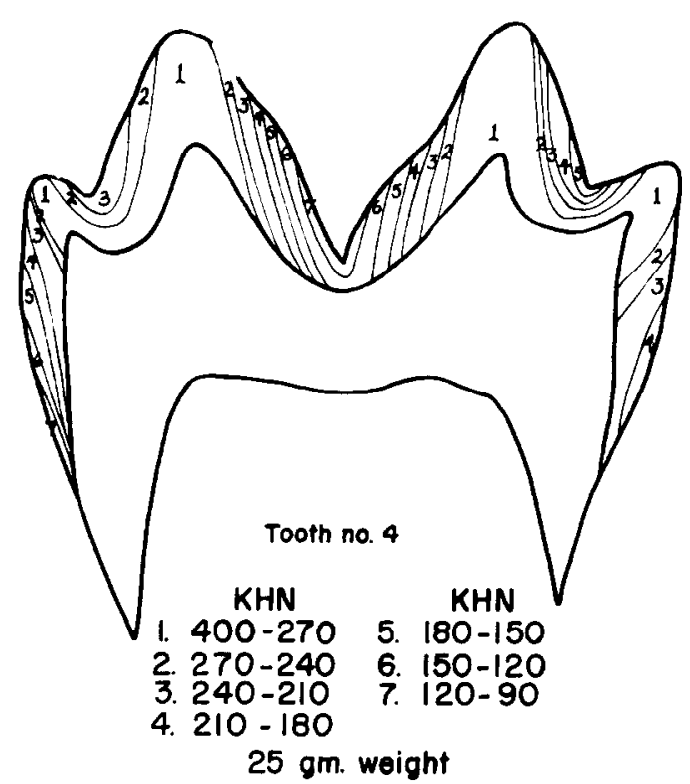

FIG. 7. Projection diagram of a mesiodistal section of a monkey molar more highly calcified than that shown in Fig. 6. The range of hardness values has decreased. Note the incremental nature of the hardness pattern. The section is from the same tooth shown in Fig. 5 which appeared uniformly radiopaque in the microradiograph.

The microhardness measurements confirm the microradiographic findings regarding not only an incremental pattern of mineralization but also the different appearance of alternating Schreger bands. Those bands which represent a crosssection of enamel rods were found to be softer than those representing the longitudinal aspect of the rods (Fig. 9).

\section{DISCUSSION}

A radiopaque line seen in the microradiographs along the dentino-enamel junction of young teeth has been noted by other investigators. ${ }^{(2,6,8-12,19,20)}$ It is possible that this 35- to 50- micra band plays some role in succeeding enamel mineralization. It is of interest that two different fiber types, each with apatite crystals of a different size, are intermingled in this zone. The enamel matrix fibers which are $50 \AA$ in width ${ }^{(24)}$ have crystals of $400-500 \AA$ in width, ${ }^{(23)}$ while the $600 \AA$-wide collagen fibrils of dentin ${ }^{(23)}$ have several smaller crystals within a single fiber. ${ }^{(24)}$ The specific nature of crystal formation in respect to a specific fiber is clearly shown in the area 
of the dentino-enamel junction. The evidence that mineralization follows enamel matrix formation in a nearly incremental fashion suggests that time may be an important factor in the changes which the matrix undergoes before crystal nucleation and growth can occur.

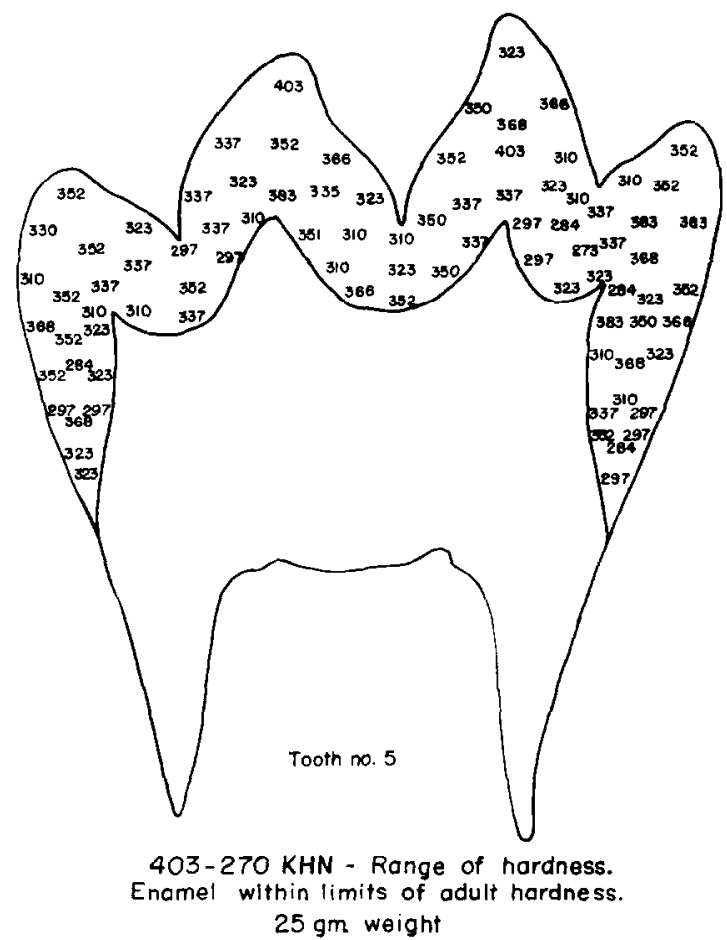

FIG. 8. Projection diagram of a mesiodistal section of a monkey molar near eruption. All measurements are within the range of adult hardness and no incremental pattern of hardness is found.

Previous studies indicate that the interrod matrix forms before the rod matrix ${ }^{(23,29)}$ and contains mineral. ${ }^{(30)}$ The rod matrix completely calcifies before the interrod substance, however. This observation may be important to understanding how the enamel may calcify from the dentino-enamel junction peripherally. The interrod space is a logical route for calcium and phosphate ions to diffuse along and around the entire length of the developing enamel rod. After the rods are completely calcified, the interrod substances then calcifies.

This pattern of enamel rod-interrod calcification may offer insight into caries of enamel as the interrod substance is the first area to be affected in this case. ${ }^{(31-34)}$ The similarity in the steps leading to the formation and destruction of enamel thus appear to be related. It is now important to gain information concerning the differences in the structure and solubility of the mineralized rod and interrod substances. 


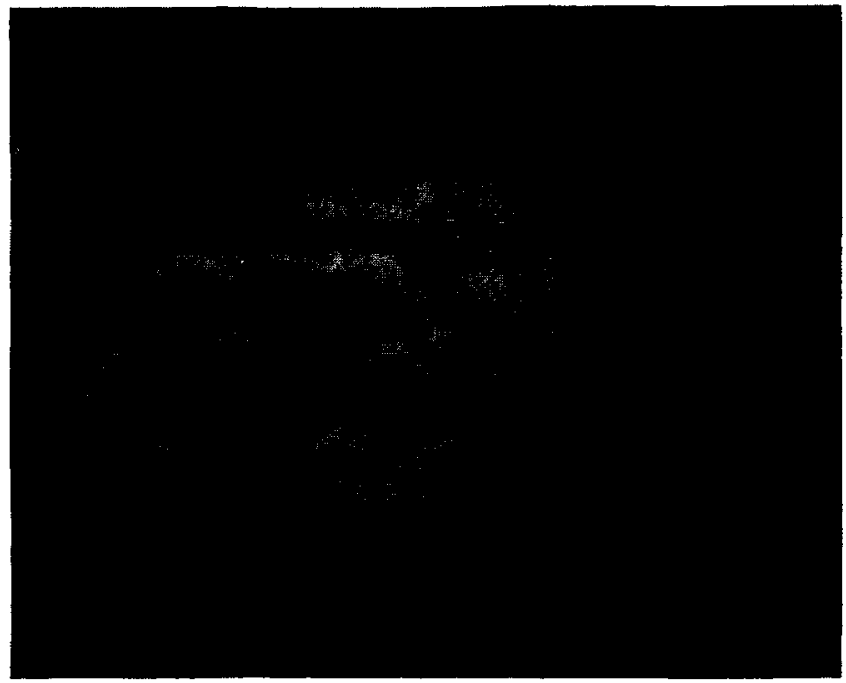

FIG. 9. Photograph of microhardness indentations in developing enamel illustrating the difference in hardness of alternating Schreger Bands. The'rod ends appear to be less hard than the rod sides.

Figures 3, 4, 5, 6, 7 and 8 are reprinted from the J. dent. Res. 40, 5, Oct. 1961.

\section{CONCLUSIONS}

1. A close relationship was found to exist between the pattern of enamel matrix formation and calcification.

2. A band of highly calcified enamel appeared along the dentino-enamel junction during early matrix formation.

3. The appearance of radiopacity along the incremental lines was a characteristic of early mineralization.

4. A diffuse mineralization then proceeded from the dentino-enamel junction peripherally which obscured the incremental lines.

5. Final calcification of the interrod substance occurred at a later stage in enamel mineralization.

Acknowledgements-The author wishes to express appreciation to Drs. R. Visser and D. Knapp for their research findings contributing to this paper and to Miss Elizabeth Haley for her assistance in carrying out the study.

\section{REFERENCES}

1. HALs, E. Fluorescence Microscopy of Developing and Adult Teeth. Oslo, Norway: Norwegian Academic Press, 1953.

2. Engfeldt, B. and Hammarlund-Essler, E. Studies on Mineralized Dental Tissues. IX. A Microradiographic study of the Mineralization of Developing Enamel, Acta Odont. Scand., 14, $273,1956$.

3. EBNER, V. voN. Über die histologischen Veränderungen des Zahnschmelzes während der Erhärtung insbesondere beim Menschen, Arch. f. mikr. Anat. 57, 18, 1906.

4. SснміDт, W. J. Doppelbrechung und Feinbau des Zahnschmelzes. Sitzber. Niederrhein. Ges. Natur-u. Heilk., Naturwiss., Abt. P, pp. 1-19, 1923. 
5. Chase, S. W. The Nature of the Enamel Matrix at Different Ages, J. Amer. dent. Ass., 22, 1343, 1935.

6. Harders-Steinhauser, M. Die Erhärtung des Zahnschmelzes nach polarisationsoptischen Untersuchungen, Z. Zellforsch. 28, 274, 1938.

7. Nuckolls, J., Leicester, H. M. and Deinstein, B. Amelogenesis, I. Am. Col. Den., 14, $118,1947$.

8. Hammarlund-Essler, E. A Microradiographic-microphotographic and X-ray Diffraction Study of Human Developing Enamel, Trans. Roy sichools Dentistry, Stockholm and Umea, No. 4, p. $15,1958$.

9. AllaN, J. H. Mineralization of Human Enamel, Nature, 180, 1362, 1957.

10. Allan, J. H. Investigation into the Mineralization Pattern of Human Dental Enamel, $J$. dent. Res. 38, 1096, 1959.

11. Crabb, H. S. M. and Darling, A. I. Observation on the Pattern of Mineralization of Human Dental Enamel, J. dent. Res. 37, 750, 1958 (abstr.).

12. Crabb, H. S. M. The Pattern of Mineralization of Human Dental Enamel, Proc. Roy. Soc. Med. 52, 118, 1959.

13. Beust, T. B. von. Intrafollicular Enamel Development, J. Amer. dent. Ass., 15, 2021, 1928.

14. Mellanby, M. Diet and Teeth: An Experimental Study. I. Dental Structures in Dogs, Spec. Rept. Ser. Med. Res. Council, London, No. 140, 1929.

15. Mellanby, M. Diet and Teeth. III, ibid., No. 191, 1934.

16. Kitchin, P. C. Some Observations on Enamel Development as Shown in the Mandibular Incisor of the White Rat, J. dent. Res. 13, 25, 1933.

17. Diamond, M. and Weinmann, J. P. The Enamel of Human Teeth. New York: Columbia University Press, 1940.

18. Weinmann, J. P., Wessinger, G. D. and Reed, G. Correlation of Chemical and Histological Investigations on Developing Enamel, J. dent. Res., 21, 171, 1942.

19. Glock, G. E., Mellanby, H., Mellanby, M., Murray, M. M. and Thewlis, J. The Study of the Development of the Enamel in Dogs, J.dent. Res. 21, 183, 1942.

20. Applebaum, E. Grenz Ray Studies of Enamel Matrix Formation and Calcification, J. dent. Res. 22, 7, 1943.

21. Marsland, A. E. A Histological Investigation of Amelogenesis in Rats. II. Maturation, Brit. dent. J. 92, 109, 1952.

22. Belanger, L. F. The Mineralization of Rat Enamel in the Light of $\mathrm{Ca}^{45}$ Autoradiography and Microincineration, J. dent. Res. 36, 593, 1957.

23. Watson, M. L. and Avery, J. K. The Development of the Hamster Lower Incisor as Observed by Electron Microscopy, Am. J. Anat. 95, 109, 1954.

24. Frank, R. M., Sognnaes, R. F. and Kern, R. Calcitication of Dental l'issues with Special Reference to Enamel Ultrastructure, in Calcification in Biological Systems, p, 163. Washington, D.C.: American Association for the Advancement of Science, 1960.

25. Leblond, C. P., Belanger, L. F. and Greulich, R. C. Formation of Bones and Teeth as Visualized by Radioautography, Ann. N.Y. Acad. Sci. 60, 631, 1955.

26. Kumamoto, Y., and Leblond, C. P. Radioautographic Study of Mineralization of Growing Teeth with Labeled Calcium, J. dent. Res. 35, 147, 1956.

27. CrabB, H. S. M. and Darling, A. J. The Gradient of Mineralization in Developing Enamel, Arch. oral Biol., 2, 308, 1960.

28. Craig, R. G. and Peyton, F. A. The Microhardness of Enamel and Dentin, J. dent. Res. 37, $661,1958$.

29. Quigley, M. B. Electron Microscopy of Developing Enamel Matrix in the Syrian Hamster. J. dent. Res. 28, 180, 1959.

30. NYLEN, M. U. and ScoTT, D. B. Electron Microscopic Studies of Odontogenesis, J. Indiana dent. Ass., 39, 406, 1960.

31. Hals, E., Morch, T. and SAND, H. Effect of Lactate Buffers on Dental Enamel in vitro as Observed in Polarizing Microscope, Acta Odont. Scand. 13, 185, 1955.

32. Guzman, D., Brudevold, F., and Mermagen, H. A Soft Roentgen-Ray Study of Early Carious Lesions, J. Amer. dent. Ass., 55, 509, 1957. 
33. Newbrun, E., Brudevold, F. and Mermagen, H. A Microradiographic Evaluation of Fissures and Grooves, J. Amer. dent. Ass., 58, 26, 1959.

34. Newbrun, E., Brudevold, F. and Mermagen, H. A Microroentgenographic Investigation of Demineralized Enamel, Comparing Natural and Artificial Lesions, Oral Surg., Oral Med., Oral Path. 13, 576, 1959. 